\title{
The impact of "policy paradigms" on energy security issues in protracted conflict environments: the case of Cyprus
}

\section{Vasileios P. Karakasis}

Teaching Staff Member at the Faculty of Governance and Global Affairs (FGGA) of Leiden University, Netherlands; Dual Ph.D. Candidate at the Graduate School of Leiden University, Netherlands; Course Coordinator for Sen Foundation for Research and Education on International Cooperation, Netherlands.

\begin{abstract}
The research question that this article attempts to address is: what are the main policy paradigms that guide the opinion leaders throughout energy security matters within protracted conflict environments? Using the de facto divided island of Cyprus as our single case study, we will deliberately follow grounded theory in order to create conceptual definitions out of rudimentary "working ideas" that involve "protracted conflict environment", "energy security" and stakes in "decision making". This research enterprise involves openended interviews with the opinion-makers on the Island and "political discourse analysis" that identifies the quintessential aspects of the recently emerged energy debate. Drawing upon the work of Correlje and van der Linde (2006), we highlight two main paradigms: "markets and institutions" and "regions and empire". In the first one, the business logic prevails upon political expediencies and geopolitical calculations, while in the second one, national and security concerns outweigh the business logic and the potential international economic integration. Through their interaction, we seek to explore how they drive the debate on energy security within the realm of a conflict environment.
\end{abstract}

Key words: energy security, Cyprus conflict, policy paradigm, markets and institutions, regions and empire.

JEL Classification: D74, G18, Q4.

DOI: $10.21272 / \mathrm{sec} .1(2) .5-18.2017$.

(C) The Authors, 2017. This article is published with open access at ARMG Publishing.

\section{Introduction}

Since the 1960s, after it gained its independence from Great Britain, Cyprus has become the battleground between Cypriots of Greek and Turkish origin. After the fall of the Berlin Wall, Nicosia still remains the last divided capital in the world, by a green line between the Greek-Cypriot administered Republic of Cyprus $(\mathrm{RoC})^{1}$ in the south and the self-declared "Turkish Republic of Northern Cyprus" in the north, excluding the British sovereign bases in Akrotiri and Dhekelia ${ }^{2}$. The leaders of the two sides, along with a host of international officials, have unsuccessfully negotiated, so far, the termination of a 43-years partition, involving an array of issues like property, governance, economy, territory and security guarantees. Both leaders have seemingly agreed to omit any substantive discussion of a particularly thorny issue - the gas reserves that were recently detected off the southern side of the Island. It is argued that a potential energy boom around Cyprus could spur on a deal between the historic competitors. Nevertheless, this has not been the case; so far, at least.

The author intends to highlight the main arguments that the opinion-makers in Cyprus have "injected" into the ongoing energy debate on the Island. What are the main stakes they attach to the future monetization of the gas reserves? Which factors encourage the cooperation between the competing sides and which ones sustain the current impasse? The research question he seeks to address is: what are the main policyparadigms that guide the opinion-leaders throughout energy security matters within protracted conflict environments? Using Cyprus as our single case study, we will deliberately follow an inductively oriented approach in order to establish conceptual definitions out of rudimentary "working ideas" like "energy security" and "factors in decision-making".

\footnotetext{
${ }^{1}$ Whose authority is recognized by the $\mathrm{UN}$ for the entire island.

${ }^{2}$ Recognized only by Turkey.
} 
To this effect, the paper is divided into three distinct sections: the theoretical, the ontological and the methodological. The first is further segmented into three parts. In the first part the author touches upon the concept of "policy-paradigm" in order to theoretically reflect on the driving forces that motivate or inspire the policy-makers and opinion leaders to cope with a problem in one way or another. In the second part he delineates the notion of energy security and forges theoretical linkages between the concepts of policy paradigm and energy security. The author uses the work of Correlje and van der Linde (2006), which succinctly depicts this interplay via the presentation of two contrasting storylines: "markets and institutions" and "regions and empire". For the needs of this article, the two storylines are identified as the contrasting policyparadigms on energy security. Through their interaction, we seek to explore how these ideational stimulants prompt the debate on energy security within the realm of a conflict environment.

In the second section, he outlines the ontological considerations attached to this topic. The author, first, exposes the historical particularities of the protracted Cyprus question. In the second part, he narrates how the seeds of the energy debate were sown and describes the role of gas in global politics in general. He then drags the discussion into the existing regional realities. What is the amount of the proven and estimated gas reserves in the region? How have the delimitation zones in the Eastern Mediterranean been formulated? On which grounds are Turkey and the Turkish-Cypriots disputing the legal status quo? Which companies have been involved in the extraction and production of these reserves so far?

The author then moves to the methodological section that aims at exploring which discourses, under the umbrella of the one or the other policy-paradigm, fuel the energy discussion on the Island. He uses grounded theory and qualitative interviewing in order to generate data by collecting the opinions of grassroots' academics, energy businessmen, policy-makers and policy advisors. In doing so, he engages in what is known as "political discourse analysis" to identify the quintessential aspects of the political discourses attached to the two paradigms. Finally, he analyzes the results and conclusions from this categorization.

\section{Theoretical section}

\section{Policy paradigm}

From a constructivist point of view, in order to perceive and simplify complex realities, every policy-maker resorts to his own "cognitive map" of politics. A good understanding of the actor's beliefs facilitates the researcher in his attempt to clarify the general criteria, the stakes that leaders set out in order to assess the arising political opportunities within such conflict environments, to estimate the costs and risks associated with them and to make utility calculations.

For the sake of their calculations, policy-makers may use encoded experience. The goals that they pursue at any moment in time, are influenced by "policy legacies" or "meaningful reactions to previous policies", conflicts and crises (Weir and Skocpol, 1985). Due to the lessons deduced from these experiences, they cultivate a "policy learning process" which deliberately endeavors to "adjust the goals or techniques of policy in the light of past experience and new information" (Hall, 1990: 7). The 'learning processes' drive them to customarily operate within a context of ideas and standards which specify not only the objectives of their policy reactions towards problems, but also the very notion of the problem they are assigned to tackle (Karakasis, 2013: 227). This system of ideas facilitates the implementation of the policy making process, not just by serving as road map, but by providing discourse schemas that actors adopt in order to make their own road maps comprehensive, convincing and legitimate to their constituents (Campbell, 1998: 381).

Peter Hall (1990) has named this very system as "policy paradigm". It implies a set of cognitive and moral maps that orients an actor within a policy sphere and functions as a tool for the actors involved in policy making to identify problems, specify and prioritize their interests and goals (Bleich, 2002).

Considering the ambiguity about the energy security debate on the Island, a better appreciation of policy paradigms is anticipated to more adequately explain the stakes behind the energy security discourses.

\section{Energy security and policy paradigm}

Energy security has appeared as a straightforward concept in global politics: "the uninterrupted availability of energy sources at an affordable price" (IEA). However, history has shown that conceptions of energy security might vary in national styles, geology, geography, and time (Sovacool and Brown, 2010: 80). The modern version of energy as a security concern firstly emerged on the radar in the dawn of the nineteenth century, when the "mechanization of warfare accelerated the energy requirements for coal-powered war- 
ships and vehicles (ibid)." For most of the 20th century, these concerns, as manifested through two world wars, were almost exclusively associated with oil and coal supply (Yergin, 2009: 773). In the 70s' these concerns had reached their peak when Western society, almost in its entirety, struggled to overcome the economically disastrous implications of the 1973-74 and 1979-80 oil crises.

At the start of the $21^{\text {st }}$ century, widespread concerns are expressed again about the security of oil and gas supply. Multiple factors opened the Pandora box of the European anxieties with respect to its energy supplies: the instability in some oil-exporting states as the turmoil of Arab Spring swept over much of North Africa and part of the Middle East in 2011 and 2012; the rise of jihadist terrorism in the same region; additionally, the revival of resource-nationalism and geopolitical rivalries-manifested through the three Ukrainian crises (2006, 2009, 2014) and the subsequent cut-off of Russian gas supplies to Europe (Yergin, 2012: 267).

Nevertheless, the ambiguous term of energy security entails something more than countering the wide variety of threats. It mirrors the relations among nations, the modality of their interaction, and the impact of energy on their overall national security. A country's ability to access energy supplies and the ways in which it uses energy, determine, to a great extent, the state of its national security (Shaffer, 2009). Thus, it is important to examine the interaction between politics and energy.

\section{Forging theoretical linkages between energy security and policy paradigm}

The paper draws on the work of Correlje and van der Linde (2006) because it concisely illustrates the interdependence of politics and energy through the presentation of two storylines: "markets and institutions" and "regions and empire".

In the first storyline, inspired by the premises of the neoliberal economic system (Winrow, 2016: 434), the writers describe a continuous cooperation in international political and economic institutions, supporting, as well, a constant development of the multilateral system that governs international relations (Correlje and van der Linde, 2006: 533). Throughout these lines, the energy companies are motivated by expectations of profit, whilst the business logic prevails upon states' political expediencies and geopolitical calculations.

The other storyline, dominated by a neorealist perspective, signals the break-up of the international system into competing blocks, which may engage in rivalry over the control of energy resources and markets (ibid: 536; Winrow, 2016: 434). In this context, neorealist views gain prominence. It includes, essentially, a division of the global economic system into countries and regions, on the basis of ideology, religion and (geo)political arguments (ibid: 536) and domestic calculations. National and security concerns or conflicts outweigh the business logic and the potential international economic integration. Energy companies - restrained by the rationale followed in these regions - have to pay attention to the national security perspectives of the actors involved.

How these storylines are manifested in the energy debate on the Island is at stake in this paper. We assume that both rationales inspire the opinion-leaders in the formulation of their energy security strategy. This begs the question of how they actually communicate them. Caroline Kuzemko (2014) embarked upon a similar initiative in her endeavor to highlight the role of ideas as key explanatory variables in the power relations between EU and Russia on energy security matters. She identified the ability of ideas to be influential in energy policy while setting forth which ideas become relevant through their interaction with concepts of power, legitimacy and identity (ibid).

The above narrated storylines inform us on the rationale guiding the opinion-leaders in setting forth their policy suggestions. They identify the stakes and considerations that the opinion-leaders inject into their energy security discourses. That is why, for the sake of this paper, the author identifies these storylines as the contrasting policy paradigms. It is illuminating to figure out how they actually unfold within a framework characterized by the legacies of conflict, mutual distrust and antagonism.

\section{Ontological considerations}

\section{Geographical and historical background of the conflict}

Being situated in the Eastern Basin of the Mediterranean Sea, the island of Cyprus possesses a central position in the global politics due to its location at the juncture of Eurasia with Africa. Cyprus has historically witnessed the invasion, the establishment and the interaction of all the ancient civilizations of pre-history and proto-history projecting it into a "crossroad of civilizations". Hellenic tribes (Arcadians, Achaeans and 
Mycenaeans, the Ptolemy dynasty) - settled in Cyprus contributing to the formulation of the Hellenic character of the Island. During Eastern Romans' era, the Christian Orthodox character of its spiritual and cultural identity was molded ${ }^{3}$. Between 1571 and 1878 the Ottoman Empire ruled over Cyprus, playing a catalytic role in forging the Turkish Cypriot identity of some of its constituents.

In 1878, at the culmination of the Great Eastern Crisis and in fear of an eventual Russian expansion into its territories, the Ottoman rule over Cyprus substantially ended. Sultan Abdul Hamit II ceded the administration of the Island to the British authorities in exchange for formal guarantees to protect the integrity of the Ottoman borders from Russian expansionist aspirations. Even from the first year of the British occupation, various discontents awakened "philhellenic aspirations" in certain urban circles. The claim for "enosis" was fundamentally considered as an extension of the $19^{\text {th }}$ century Greek irredentist nationalism and "subsequent struggles to incorporate Greek speaking regions of the old Ottoman Empire into the Modern Greek state" (Stavrou, 2009: 7). On the other side, the Turkish Cypriots considered the Island part of the Ottoman territory.

In 1914, at the outbreak of WWI and after the Ottomans' decision to align their forces with the opponents the Central Powers - of the Entente, the British annexed the territory de jure. Greek Cypriots envisaged in this evolution the avenues for the realization of their "enosis" aspirations. In 1931 these aspirations boiled over with a spontaneous rebellion against the British rule, leaving Government House in flames (Anderson, 2008). As a response, the British administration suspended the colony's Constitution and decreed any agitations related to "enosis" punishable (ibid). In 1950 the Church mobilized mass popular support for "enosis" by conducting a "plebiscite'. 96\% of the participants supported the union with Greece. On the other side, Turkish Cypriots, who had already formulated $\mathrm{KATAK}^{4}$ in 1943, organized demonstrations against these aspirations (Interview with Kizilyurek on 20.11.2014). They came to embrace partition, "taksim", as the main goal of the Turkish Cypriot nationalism in order to counterbalance the Greek-Cypriot claim for "enosis".

Greece's initiatives to project the Cyprus issue into the agenda of the 9th session of the General Assembly in the UN (1954-1955) fell short of its objective to mobilize international support for the "enosis" cause. Great Britain unveiled its concerns that a potential internationalization of the issue by the Greeks, without first informing the Turkish government, would flare up the Turkey's fears that Greece was setting up a territorial claim on the Island. The British attitude provoked, thus, the first Turkish involvement in the Cypriot state of affairs after 1878 and revitalized the Turkish Cypriot nationalistic sentiments for "taksim".

In 1955, after the failure of protracted negotiations between the Island's new governor, Field Marshal Sir John Harding and Archbishop Makarios III, an outbreak of anti-British military activities by EOKA, ${ }^{5}$ took place (Spyridakis, 1974: 177). The British undertook an intensive campaign to exterminate EOKA and Makarios was exiled to The Seychelles a year later. Evoking the explosive situation in the Island, Great Britain initiated a Tripartite Conference (Greece, Turkey, UK) in London to determine the Island's political future but no solution was reached. It remained, however, significant since, on the one hand, it officially marked the beginning of the active participation of Turkey in the Cyprus question and, on the other, the minority status of the Turkish Cypriots got upgraded into a community status (Blay, 1981: 80). These two agreements created a "free state" - whose territorial integrity was guaranteed by the UK, Greece and Turkey, "but not a nation" of Cyprus (Spyridakis, 1974: 184).

After intense haggling and negotiations, a series of international agreements - concluded in Zurich and London in 1959 and 1960 - gave birth to the Republic of Cyprus (RoC). It was conceived as a bi-communal state where power would be shared between its two constituent communities: the Greek-Cypriots and the Turkish-Cypriots. Its territorial integrity would be guaranteed by three guarantor powers: Greece, Turkey and Great Britain. In its very infancy, the newly-founded state was not the beloved child of its inhabitants since it cropped up as the accidental offspring of violent conflicts during the 1950s. The multiple checks and balances included within these accords, inhibited the functional operation of the Constitution. The amendments submitted by the restored President Archbishop Makarios III in 1963 encountered Turkish and Turkish-Cypriot rejection resulting in a constitutional deadlock accompanied by violent clashes between the two communities. British troops intervened by establishing the buffer zone marked by a 'green line' between the

\footnotetext{
${ }^{3}$ The establishment of the Apostolic Church of Cyprus by Saint Paul and Saint Barnabas had already taken place in 46 AD.

${ }^{4}$ Kıbris Adası; Türk Azınlık Kurumu. The Association of the Turkish Minority of the Island of Cyprus.

${ }^{5}$ On the $1^{\text {st }}$ of April 1955 EOKA - a Greek acronymic meaning for "National Organization of Cypriot Fighters" - under the leadership of the retired Colonel George Grivas, declared that the Cyprus revolution had begun.
} 
two camps, and thereby paving the way for the UN peacekeeping mission in 1964 and for Secretary General's (SG) "good offices".

The political turmoil in Greece - culminating in the establishment of the military regime in 1967 - and the inter-communal tensions in November 1967 (bombing of villages and forces by both sides) brought the negotiations to an impasse. In May 1968 the dialogue was resumed for almost six years, but terminated in the summer of 1974. A coup d'état against Macharios III, engineered by the then Greek military dictatorship, was followed by Turkey' military invasion, which altered the demographic structure of the RoC and resulted in a massive social dislocation of both Greek - and Turkish Cypriots. Turkish forces occupied 37\% of the Island and since then have kept around 35,000 troops on it. Turkish officials justified their military intervention (which they have called a "peace operation") upon security considerations and started bringing settlers from the Turkish mainland to the Island in order to bolster the population of the north. In the light of these events, the Security Council (SC) passed several resolutions calling unsuccessfully for a ceasefire, an immediate termination of the foreign military intervention and the withdrawal of all the forces except for those, whose presence was authorized by the accords.

Nevertheless, after the de facto division, a parallel administration, which the Turkish Cypriots had been running in the decade 1964-1974 evolved into a "self-governing" status in the north. SG Waldheim relaunched the framework of good offices in order to overcome the impasse. The idea of a bi-zonal bicommunal federation, as the outcome of the Denktash-Makarios' communal talks, has been accepted as the blueprint for a solution since 1977. Nonetheless, successive leaders have not shared a common view of the legal and political consequences that this very solution implies. In 1983, the Turkish Cypriots declared their independence, a development that the SC has condemned via successive resolutions. Despite the innumerable UN mediations, the efforts of the international community to bring about a solution have proved ineffectual. The last integrated international effort through the UN sponsored Annan Plan, was rejected by the Greek-Cypriots after having been put to a referendum in 2004. The RoC got admitted to the EU in 2004 without a settlement, making Turkish and Turkish-Cypriots question EU's reliability as an impartial broker in the Cyprus issue. Hence, the negotiations have gone back and forth and have failed, so far, in reaching a peaceful settlement.

How is the situation nowadays? On the south there is the Republic of Cyprus, administered by the GreekCypriots, member of the EU and the UN and, in general, a functioning, prosperous and well-governed democratic state with one of the highest levels of GDP per capita. However, their economy tipped into recession in 2009 as the ongoing global financial crisis and the resulting low demand hit their main economic pillars, the tourism and construction sectors (CIA Factbook). An overextended banking sector with excessive exposure to Greek debt added to the contraction. After numerous downgrades of its credit rating, RoC lost access to international capital markets in May 2011. Two months later, the situation deteriorated when containers of explosives, stored for some years in a naval base self-detonated and killed 13 people, injured 62 and damaged the Island's largest power station designed to supply over half of Cyprus' electricity (Athanasiou, on 11.7.2011).

In July 2012, RoC became the fifth euro-zone government to request an economic bailout program from the "Troika". There is the self-styled "TRNC", not recognized by any state of the international community (except for Turkey) - as the outcome of consecutive SC resolutions - that deals with an embargo put on its ports and relies heavily on Turkish military and economic support. Its economy is dominated by the services sector, which includes the public sector, trade, tourism, and education (ibid).

In the paragraphs above we delineated the historical background of the conflict by setting forth those events that have consolidated the de facto division on the island and the protracted character of the conflict. Within this context, we will lay out the opening of a new chapter, which is the energy debate.

\footnotetext{
${ }^{6}$ That is an old diplomatic institution - facilitating dialogue between the disputants.

${ }^{7}$ Composed of the European Commission, European Central Bank and the International Monetary Fund. After the election of President Nikos Anastasiades in February 2013, Cyprus reached an agreement with the Troika on a bailout that resulted in losses on uninsured bank deposits triggering a two-week bank closure and the imposition of capital controls that remained partially in place until April 2015 (CIA Factbook).
} 
The ontological framework of the energy debate around the Island: exploratory, legal and economic parameters

We will concentrate now on the recent gas developments around the Island. The author, herewith, shortly presents the role of natural gas (NG) in global politics and narrows the discussion down to the gas developments in the Eastern Mediterranean.

The 1973 Arab oil embargo amplified the impetus for the increasing role of gas in the energy supply. The shortages and spiking prices as the outcome of the embargo encouraged many countries to diversify away from the Middle East oil and shifted gas from a cluster of regional markets into a global marketplace (Barne et al 2006: 8), although it cannot be considered as a global commodity in its own right. NG is produced, transported, and traded through regional, fragmented markets (Saz Carranza \& Vandendriessche, 2015). It is difficult to transport it and requires a network to be delivered (through a pipeline or a regasification plant). It relies on a system of logistics and transportation which is fixed and much less flexible than the existing ones for oil. Furthermore, the majority of NG pricing worldwide is long term and linked to oil prices. These longterm, oil indexed contracts, which typically include take-or-pay clauses ${ }^{8}$ provide a boost to immature markets, because their reliability safeguards the infrastructure investments required for NG trade (ibid.).

These properties make NG inherently geopolitical. The above described infrastructure is extremely costly to build and conditioned upon long-run horizons as well as a predictable geopolitical and economic context that will enable investors to "sink their capital and knowledge" (Barnes et al., 2006: 3). Due to the stateregulated sphere, within which the gas market is operating, governments, by contrast with the oil market, are urged to play a larger role in the NG trade. Thus, states, in choosing routes to export their commodities and import their energy supplies, naturally consider and promote the political ramifications of various route options (ibid).

The way this has been displayed around Cyprus will be explained in the following section.

\section{The case in the Eastern Mediterranean: exploratory, legal and economic context}

Much of the hydrocarbons in the Eastern Mediterranean have gone undiscovered because the resources lie in the seabed under very deep waters. These depths exceed two $\mathrm{km}$ in some locations and made drilling in the area a difficult, risky and expensive business. At the dawn of the 21st century, recent technological advances, accompanied by high international oil prices, prompted new exploration initiatives. The rapid advances in micro-processing made the analysis of vastly more data possible and facilitated geophysicists in greatly improving their interpretation of underground structures and, consequently, exploration success (Yergin, 2011: 40). These technological advances had an enormous impact on the energy developments around Cyprus as well. In March 2010, the U.S Geological Survey estimated a mean of 122 trillion cubic feet of recoverable gas in the seabed of Levant Basin Province, located along and off the coast of Syria, Lebanon, Israel, and the Gaza Strip, extending westward into Cypriot waters (see Figure 1. Levant Basin: Oil \& gas finds).

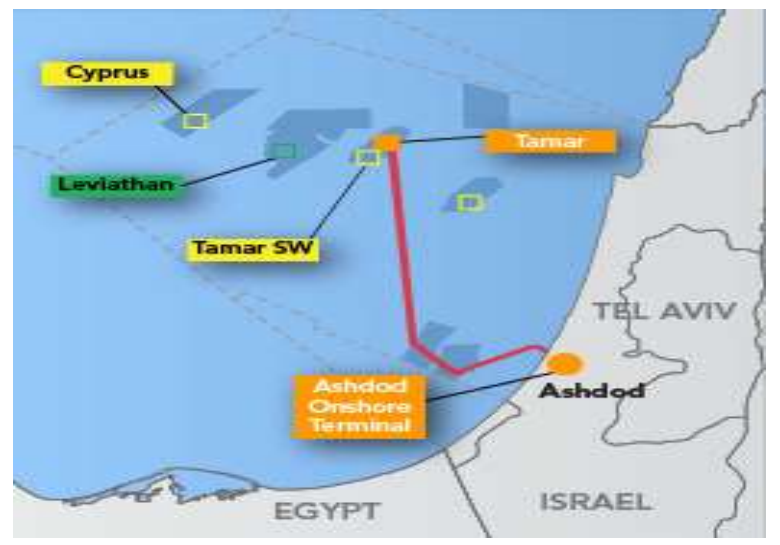

Figure 1. Levant Basin: Oil \& gas finds

Source: Noble Energy.

\footnotetext{
${ }^{8}$ Which means specifying a minimum, pre-set volume of gas per year that the buyer will pay for at the contract price, regardless of whether the volume is consumed or not
} 
After having proclaimed its EEZ and signed delimitation agreements with Egypt (2003), Lebanon (2007) and Israel (2010), RoC demarcated the outer limits of a $51 \mathrm{~km}^{2}$ exploration area and carved it into 13 blocks (see Figure 2). The agreement with Israel marked the beginning of an increasing collaboration between the two, an initiative joined by Greece as well. The Israeli and Greek Navies joined forces conducting jointdrills in the region. This trilateral collaboration was given an extra impetus after the Gaza flotilla raid incident in May 2010 and the deterioration of the relations between Israel and Turkey ${ }^{9}$. Collaborations of a similar nature between Egypt, Cyprus and Greece were also noticeable during that period.

Since 2008, the government of RoC had already awarded one license to the small-sized Noble Energy, which had been operating offshore Israel. After multiple seismic surveys of Noble, the first exploratory drilling unfolded in Block 12 in September 2011. Two months later, the company indicated a 5-8 tcf natural gas deposit in deep waters. This discovery, albeit of small importance, triggered a significant interest in a second offshore licensing round in February 2012 with the participation of 15 bidders, including bigger international oil companies and gas traders. The Italian ENI, the French Total and the Korean Kogas were accredited with the exploration of six more blocks $(2,3,9,6,8,11)$. In December 2016 a third licensing round took place and a consortium between the American giant Exxon Mobil and Qatar Petroleum won the bid to launch drilling in one more block 10 .

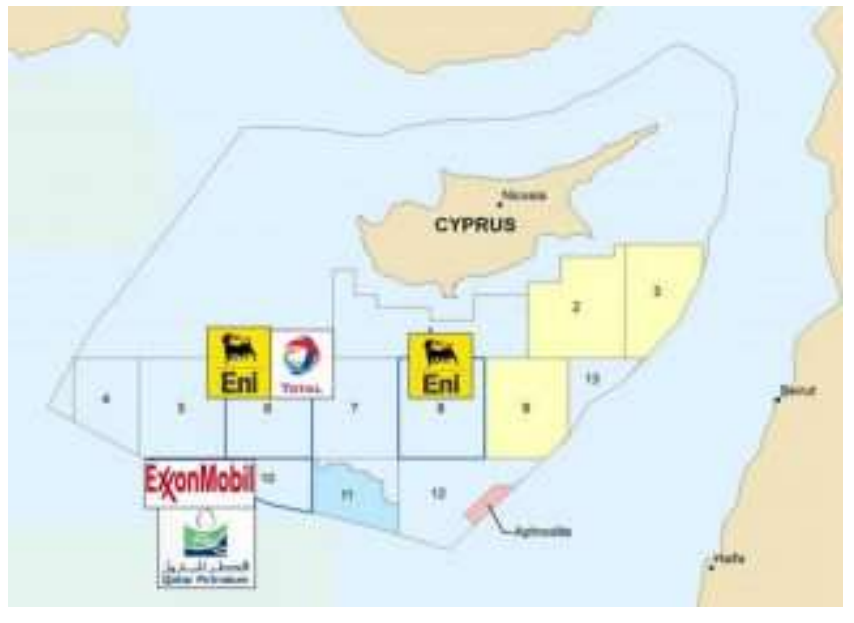

Figure 2.13 blocks as divided by RoC

Source: Offshore Energy Today.

Turkey, one of the guarantor powers on the Island, fiercely objected to all actions taken by the RoC with regard to its EEZ claims and offshore hydrocarbons development (Gurel \& Le Cornu, 2014: 18). Turkish and Turkish Cypriot officials argued that any unilateral Greek Cypriot action in this field, before a settlement is reached, would not only ignore the legitimate rights of Turkish Cypriots, but would establish a fait accompli prejudicing the terms of a prospective arrangement on sovereignty issues to the disadvantage of the Turkish Cypriots. On 21 September 2011 and as a reaction to the launch of the exploratory drilling by the RoC government, the Turkish Cypriots signed a continental shelf delimitation agreement with Turkey. The contributing parts drew a boundary line between the northern coast of Cyprus and the southern coast of Turkey in the Mediterranean Sea. In doing so, Turkish Cypriots and Turks dispatched a seismic vessel, Piri Reis, and issued licenses to TPAO to conduct a three-dimensional seismic research along with onshore and offshore drillings around the recently traced maritime borders between them. A couple of years later, in October 2014, a Turkish navigational warning notified mariners that Turkey would soon repeat its seismic surveys in sea areas encroaching on Cyprus's EEZ. This action urged the Greek Cypriot leader to pull out of the ongoing reunification talks. In the meantime the drilling has been stalled and is expected to re-launch in July 2017.

\footnotetext{
${ }^{9}$ The flotilla, organized by the Free Gaza Movement and the Turkish Foundation for Human Rights and Freedoms and Humanitarian Relief (iHH), was carrying humanitarian aid to terminate the Israeli blockade of the Gaza Strip. Israel reacted through a military operation -against six civilian ships of the "Gaza Freedom Flotilla" in international waters of the Mediterranean Sea- during which nine activists were killed in one of the six ships: the Mavi Marmara.
} 
Having laid out the historical, exploratory, legal, economic and political framework within which the energy game unfolds, we will go on with highlighting the stakes that the opinion-leaders attach to it.

\section{Methodology}

The stakes, as conceptualized in the theoretical framework, are the policy-paradigms. The author wants to progressively identify them through the collection of some observations he made when he visited the island of Cyprus in 2014 and 2015. This specific type of inductive theorizing that he embarks upon, is grounded theory. In line with this rationale, he had to collect data and analyze them simultaneously from the preliminary stages of his research. Having certain sensitizing concepts in mind (protracted conflict environment, energy security, policy paradigm) - he selected a sample of opinion-leaders he deemed useful for his research in order to elicit proper information - and formed preliminary interviewing questions to open up these contrasting paradigms (Charmaz, 2011:2).

\section{Qualitative interviewing}

In this context, he talked to people coming from the energy business area, to academics with expertise in the history of the Cyprus conflict, policy advisors, former accredited negotiators in resolving the conflict, as well as former ministers of Foreign Affairs and Energy. These participants were asked to tell their story in order to facilitate the construction of the dataset about the above mentioned sensitizing paradigms. Qualitative interviews provide an open-ended, in depth-exploration of such an aspect about which the interviewees hold substantial experience, often accompanied by considerable insights (Chatmaz, 2011: 3). With respect to the RoC, and the Turkish-Cypriots, the author interviewed key figures in chronological order, as shown in Table 1 and Table 2 respectively. He approached also Dr. Tzimitras, Director of Peace Research Institute Olso (PRIO) Cyprus Centre, who has conducted numerous reports and organized several conferences in the Island and abroad around this energy debate (on 22.12.2015).

Table 1. Interviewees in RoC (in chronological order)

\begin{tabular}{|l|l|c|}
\hline \multicolumn{1}{|c|}{ Name of the interviewee } & \multicolumn{1}{|c|}{ Professional affiliation expertise } & Date of interview \\
\hline Dr. Nikos Moudouros & $\begin{array}{l}\text { Member of the Geostrategic Council of the RoC and adviser to the } \\
\text { former President of the RoC, Dimitris Christofias (2008-2013) on } \\
\text { Turkish and Turkish Cypriot issues. }\end{array}$ & 18.11 .2014 \\
\hline Pr. Andreas Theophanous & $\begin{array}{l}\text { Director of the Cyprus Center for European and International Affairs } \\
\text { and Ex Economic Advisor to Georgios Vasiliou, former President of } \\
\text { the RoC (September 1990-February 1993). }\end{array}$ & 19.11 .2014 \\
\hline Dr. Constantinos Adamides & $\begin{array}{l}\text { Assistant Professor of International Relations at the University of } \\
\text { Nicosia, member of the Geostrategic Council of the RoC. }\end{array}$ & 30.11 .2015 \\
\hline Dr. Zenon & $\begin{array}{l}\text { Associate Lecturer at UCLAN with expertise in Turkish politics and } \\
\text { foreign policy. }\end{array}$ & 3.12 .2015 \\
\hline Dr. Charles Ellinas & $\begin{array}{l}\text { CEO of Cyprus-based energy consultancy e-CNHC and former CEO } \\
\text { for the Cypriot National Hydrocarbon Company (KRETYK) }\end{array}$ & 4.12 .2015 \\
\hline Nikos Rolandis & $\begin{array}{l}\text { Former Minister of Foreign Affairs (1978-1983) and of } \\
\text { Commerce, Industry and Tourism in the coalition-government } \\
\text { formed up by the late President Clerides. } \\
\text { Pioneer in setting the offshore oil and gas reserves of Cyprus in } \\
\text { the political agenda. }\end{array}$ & 11.12 .2015 \\
\hline
\end{tabular}

Table 2. Interviewees in the northern part (in chronological order)

\begin{tabular}{|l|l|c|}
\hline \multicolumn{1}{|c|}{ Name of the interviewee } & \multicolumn{1}{|c|}{ Professional affiliation expertise } & Date of interview \\
\hline Dr. Ayla Gürel & Senior Research Consultant of PRIO. & 11.11 .2014 \\
\hline Pr. Ahmet Sözen & $\begin{array}{l}\text { Chair of the Department of Political Science and International } \\
\text { Relations at Eastern Mediterranean University (EMU) - former } \\
\text { member of the Turkish Cypriot team in the UN-led peace negotiations }\end{array}$ & 17.11 .2014 \\
\hline Pr. Niyazi Kizılyürek & $\begin{array}{l}\text { Advisor to the RoC President Nicos Anastasiades on Turkish affairs in } \\
\text { the Geostrategic Advisory Council, and Dean of the Faculty of } \\
\text { Humanities in the University of Cyprus. }\end{array}$ & 20.11 .2014 \\
\hline Dr. Hayriye Kahveci & Analyst in energy politics. & 1.12 .2015 \\
\hline Pr. Kudret Özersay & $\begin{array}{l}\text { former Turkish-Cypriot negotiator and founder of "The People's } \\
\text { Party". }\end{array}$ & 18.12 .2015 \\
\hline
\end{tabular}


Rather than asking them contrived questions designed to elicit particular sorts of data, the author asked his interviewees "real questions", which they were genuinely interested to answer. A sample of these questions is indicated in Table 3. By the collection of statements-answers to his questions after the transcription, he underlined the very parameters involved in the Cypriot energy chessboard. By putting together descriptions from separate interviewees, he constructed the policy-paradigms that drive the energy security debate in the context of a protracted conflict environment. The modality of this construction is explained in the following part.

Table 3. Type of questions asked to the interviewees

\begin{tabular}{|l|l|l|}
\hline \multicolumn{1}{|c|}{ Energy security } & \multicolumn{1}{|c|}{ Cyprus conflict } & \multicolumn{1}{c|}{ Policy paradigm } \\
\hline How do they define energy security? & $\begin{array}{l}\text { What are the main impediments in } \\
\text { reaching a settlement and looking at the } \\
\text { win-win side in exploiting these gas } \\
\text { reserves? }\end{array}$ & $\begin{array}{l}\text { Which aspects should the leaders take } \\
\text { into consideration before making a } \\
\text { decision on the monetization of gas } \\
\text { reserves? }\end{array}$ \\
\hline $\begin{array}{l}\text { What geopolitical and/or economic } \\
\text { factors have to be examined? }\end{array}$ & $\begin{array}{l}\text { What difficulties are inherited by the } \\
\text { protracted conflict? }\end{array}$ & $\begin{array}{l}\text { What are the main risks and dangers } \\
\text { attached to the implementation of every } \\
\text { decision? }\end{array}$ \\
\hline $\begin{array}{l}\text { What is the role of the international } \\
\text { (UN, USA, Russia, EU) and the regional } \\
\text { (Israel, Egypt) actors in this respect? }\end{array}$ & Which factors make the conflict sustain? & $\begin{array}{l}\text { What kind of priorities should the } \\
\text { political leaders set before sweeping } \\
\text { into the formulation of an energy } \\
\text { security strategy? }\end{array}$ \\
\hline $\begin{array}{l}\text { Which alternatives do exist for the } \\
\text { Greek-Cypriots to export their gas } \\
\text { reserves? }\end{array}$ & How does the one side view the other? & $\begin{array}{l}\text { The energy debate follows a market- } \\
\text { oriented or a geopolitical approach. }\end{array}$ \\
\hline
\end{tabular}

\section{Political discourse analysis}

In order to safeguard that his study will address the quintessentially political aspects of the policyparadigms, the author engaged in what Seidel (1985) calls "political discourse analysis". Discourses refer to communication practices that systematically construct our knowledge of reality. The stake here is to make out the "truths" on energy security issues as these stem from the transcripts of the interviews and deliberately insert them in one of the two policy-paradigms. Table 4 depicts the categories of the discourses attached to the two contrasting policy paradigms as they cropped up after the collection of the statements.

Table 4 . The contrasting policy paradigms

\begin{tabular}{|l|l|}
\hline "Markets and Institutions" & "Regions and Empire" \\
\hline Export option to Turkey & Energy as a security issue \\
\hline & Challenges for gas companies \\
\hline Export option to Egypt & The Geopolitical Chessboard: \\
& $\begin{array}{l}\text { 1. The EEZ and the dispute in the Aegean } \\
\text { 2. The formation of triangles }\end{array}$ \\
\hline The construction of LNG & Peace-negotiations, domestic politics and energy \\
\hline Gas for peace & The Legacies of the Conflict \\
\hline
\end{tabular}

\section{Discourses attached to the "markets and institutions" policy paradigm}

After having conducted the discourse analysis, the author came up with five main discourses: "the export option to Turkey", "the export option to Egypt", "the construction of LNG", and "Gas for Peace".

\section{Export option to Turkey}

The discourse that was mostly discussed in the interviews is the export option from the Israeli gas field of Leviathan to Turkey through Cyprus. Various hypotheses were set forth. The Greek-Cypriot energy affiliates and some Turkish-Cypriots portrayed it as the main viable option for the Greek-Cypriots if they want their gas to journey to Europe. The primary condition upon which this scenario could play out is the settlement of the Cyprus conflict. Some Turkish-Cypriots claimed that there are "Turkish companies lobbying" to construct this pipeline ${ }^{10}$ and Turkish diplomats were making these plans "without consulting the Turkish Cypriots." The Turkish-Cypriot side remarked that if no settlement is reached, this potential pipeline "might

\footnotetext{
${ }^{10}$ Implying probably Turcas Holding and Zorlu Group.
} 
not go through the RoC but through Karpaz", which lies in the Turkish-Cypriot controlled northern side of the Island. On the other side, Greek-Cypriots, who ruled out the possibility of the last scenario, indicated the problematic repercussions that a pipeline to Turkey would have on the RoC. For them the unilateral dependency on an unpredictable Turkey spotlighted the most serious concern.

\section{Export to Egypt}

Another discourse relates to the potential export of the gas reserves to Egypt that has two LNG termination plants at its disposal (Damietta and Idku). It was stressed though that companies will not invest in this option till the gas prices go up.

\section{The construction of an LNG}

The third discourse about this policy paradigm refers to the potential construction of LNG in the port of Vassilikos of Limassol. This option, if realized, would provide the Greek-Cypriots with a sense of flexibility in their export options. Nevertheless, it was stressed that Greek-Cypriots "under the current prices cannot take any advantage of their gas reserves because they lie offshore in ultra-deep waters".

\section{Gas for peace}

The last discourse regards the possibilities for energy to facilitate the conditions of a peaceful settlement on the Island. An idea set forth by the Greek-Cypriot side was for the Greek Cypriots to keep at the drilling activities, but under the supervision of an international authority, within which a Turkish Cypriot representative could also participate. The Turkish Cypriots would not participate in the management of these reserves but they could supervise the whole procedure joining an international banner. This proposal would include a disclaimer: whatever is agreed upon, the energy topic would not constitute a precedent for the other items of the Cyprus question. The idea for an escrow account was also suggested and espoused by some of the Turkish-Cypriot interviewees on the condition to function as an investment bank.

As to the question whether the companies could contribute to the application of a neo-functional framework in order to enhance the cooperation between Greek-Cypriots and Turkish-Cypriots, some of the reactions of the Greek-Cypriot interviewees were negative: "no company in the world would invest billions to bring about peace". They claimed that the presence of pipelines is just a reflection of peace or stability, not the other way round.

\section{Discourses attached to the "Regions and Empire" policy paradigm}

The paradigm "regions and empire" synthesizes the interplay among five main discourses: "energy as a security issue", "challenges for gas companies", "Geopolitics in the Eastern Mediterranean" (divided into three further sub-categories), "Peace-negotiations, domestic politics and gas" and "the legacies of the conflict".

\section{Energy as a security issue}

Here we place the emphasis on the role of "realpolitik" in the energy security debate. For some of the Greek-Cypriot interviewees, the whole stake in the speculations about a pipeline to Turkey is security: "opening the door to Turkey signals that the Greek-Cypriots question their sovereignty" even in the aftermath of a settlement. For them, "the national sovereignty of Cyprus should not be in jeopardy. Therefore, the Greek- Cypriots should be the ones making the decisions on their own" without the Turkish Cypriots. Turkish Cypriots, on their side, recall a resolution issued by the UNGA in 1962, "Permanent Sovereignty over Natural Resources", which attributes access rights not only to states, but also to people and nations." Furthermore, they claim that Greek-Cypriots should not project the energy issue "into the existential question for the RoC, as if the RoC's existence depends on talking about hydrocarbons with Turkish-Cypriots or not."

\section{Challenges for the gas companies}

This discourse succinctly explains the rationale as well as the obstacles that the companies have to surmount in their decision making on energy issues: waiting for the outcome for the re-unification talks, Turkey's opposition to drillings, difficulties of a bureaucratic character. Nevertheless, companies like TOTAL and ENI, for which Cyprus' entitlement in the region is strong, still keep researching in blocks 11, 2, 3, 9 despite Turkey's pressure. 


\section{The Geopolitical chessboard}

This discourse entails three sub-categories that are identified here as: "the EEZ and the Aegean dispute" 11 ", "the newly emerged triangles" and "the role of the big players".

\section{The EEZ and the Aegean dispute}

One of the Turkish-Cypriot interviewees laid out the legal parameters of the regional landscape: "There are twenty one indigenous states having shores at the Eastern Mediterranean, the majority of which does not have an EEZ, due to the nature of the Eastern Mediterranean." The same person said that when "the RoC started to sign the EEZ, there was a giant sleeping for years and the Greek-Cypriots woke him up." In this view, the stake was not only in the Eastern Mediterranean but in the Aegean Sea as well; "it was something that would not make Turkey and Greece step back."

\section{The newly emerged triangles}

Within this discourse the formation of the various cooperation schemas was discussed too. What is the nature of the triangles between Israel-Greece-Cyprus and Egypt-Greece-Cyprus? In the Greek-Cypriot view, these collaborations are oriented towards the right direction, which is the stability in the Eastern Mediterranean. The Greek-Cypriots hesitated to call them axes or alliances, although both the public and the media utilized these terms to frame the nature and modality of these relationships. The GreekCypriot interviewees notified the author that the Greek-Cypriot lack of experience and expertise "in securing their natural resources through coast-guard, navy and air-force" was the main driving force behind their initiative, given the unstable regional environment. In the Turkish-Cypriot view and due to the deterioration of Turkish-Israeli relations in the aftermath of the Mavi-Marmara incident, these triangles were perceived then in the light of "the enemy of my enemy is my friend". Furthermore, they questioned the fundamentals of these triangles by raising the following aphorism: "From the Israeli point of view, it is good to have close relations with two EU members, but this does not mean that Israel is going to sacrifice its links with Turkey for this relationship".

\section{The role of the big players}

The role of the big players could not be absent from the discussion. In the point of view of both the Turkish-Cypriots and Greek-Cypriots, "the US in the background have played a very big role in bridging the gap between the two competitors in order to "create an environment of cooperation" that would gradually stabilize the region. For both sides, the Americans want to clear the Cyprus question out of their way in order to restore their problematic relations with Turkey back to normality.

In this connection, Russia's attitude should not be overlooked. Given the Russians' ability to dock their vessels in the Greek-Cypriot ports, Greek- and Turkish-Cypriot interviewees agreed that an eventual change of the status quo might imperil Russia's interests there.

Same applies to the UK. For some of the Turkish-Cypriot respondents, the current status quo does not have a "hurting stalemate" effect on the British interests, since it embraces a level of stability, thereby enabling the UK to continue to use the sovereign bases, without any dispute.

\section{Peace-negotiations, domestic politics and energy}

The next discourse is about the role that gas developments have played in the peace-negotiations. One of the Greek-Cypriot respondents drew a sharp distinction, claiming that energy might fuel the tensions and create a problem in parallel with the Cyprus conflict; hence, it should not be put on the negotiation table. He also said that if the cooperation "in the management of these resources were a solely bi-communal issue, a modus vivendi could have theoretically been reached". Nevertheless, the difficulties crop up if the approval of Turkey to this is requested, he added. The Turkish Cypriot answer to this remark was that the presumption "that the Turkish Cypriots would prevent a decision from being taken, underlines another missing element in the Cyprus conflict; that is the federal culture."

\footnotetext{
${ }^{11}$ Which cannot be analyzed in the current paper.
} 
Another Greek-Cypriot respondent expressed a different view: "without a meeting with the TurkishCypriots - not with Turkey- to discuss on the energy issue, the Greek-Cypriots would find themselves under the "Damoclean sword" of Turkey."

This discourse illustrates the role of domestic politics in both the negotiations process and the energy policymaking. In the view of some Greek-Cypriots, the countries in the whole Eastern Mediterranean region "approached the whole energy debate purely from a political point of view, prioritizing it over the business logic." In the words of a Turkish-Cypriot interviewee, "the natural gas has been utilized for domestic consumption and not for real economic purposes." A Turkish-Cypriot interviewee claimed that the AKEL government initiated the whole endeavor in order to restore its shaken image after the Mari events in 2011 and deflect the attention from the economic reforms needed. For the same respondent the 2011 seismic crisis was not a Turkish but a Turkish-Cypriot endeavor to drag the Greek-Cypriot exploration activities into a reciprocity question.

\section{Legacies of the conflict}

This leads the author back to the story of the conflict, which constitutes, also, the last discourse-component of the "region and empire" policy paradigm. One of the respondents stated that in the case of politicalmilitary conflicts, "energy, as such, has not been, so far, a factor contributive to their resolution" but has rather evolved as "an essential chapter of the pre-existing conflict". In this view, Cyprus could theoretically become an exceptional example of energy's capacity to bring about peace, because "Cypriots deal with a manageable-dormant crisis" and "the incentives to resolve it drop day by day".

Nevertheless, the answers received from both sides provided a reality check for this assumption. From the RoC's point of view, due to the feelings of abasement Greek-Cypriots experienced in 1974, there is an honest, real and natural fear vis-à-vis Turkey in military terms. Furthermore, they are afraid that TurkishCypriots would be treated as the "Trojan horse" of Turkey. On the other side, the Turkish-Cypriots believe that the way Greek-Cypriots envisage to shape the new state, risks becoming second class citizens, deprived of any right to intervene. These fears remain intact. One of the Turkish-Cypriot respondents mentioned: "Cyprus is a space wherein resentment exists; a space in which people, communities and citizens feel underprivileged and deeply traumatized. Wherever resentment exists, the past never becomes a past." That is why a topic irrelevant to the sources of the Cyprus question - like energy - is viewed by many of the respondents through the lenses of the pre-existing conflict and becomes another chapter of the latter. Fears were also expressed - in case of a non-successful conclusion of the ongoing negotiation process - for a potential division, permanent and legitimate.

\section{Conclusions}

Through what has been recorded in the previous pages, the author sought to establish the parameters that formulate the energy debate in relation to the island of Cyprus. To this effect, he used three sensitizing concepts - protracted conflict, energy security and policy paradigm-and collected data out of his interviews with policy-makers, analysts, energy affiliates and academics, conducted in 2014 and 2015, for the purpose of exploring how they actually work in real-life politics. He resorted to a bottom-up approach in sorting out the statements he deemed useful in his effort to generate certain theories that shed light on the dynamics that sustain the debate. This approach helped him to actively listen to the concerns of the respondents and voice the stakes that should be taken into consideration.

He used the notion of "policy-paradigm" coined by Peter Hall in order to conceptualize all these different dimensions that loomed up out of the transcriptions of interviews and are attached to the energy security debate. Drawing upon the storylines of Correlje and van der Linde (2006), he classified the statements into two categories: "markets and institutions" and "regions and empire". In the first one, inspired by the neoliberal paradigm, economic-laden arguments with respect to the monetization of the gas reserves were prioritized. The stake here was to touch upon the business logic behind the debate as well as the "spill-over" effect they might have on a peaceful settlement. Consequently, he put extra emphasis on discourses like "export option to Turkey", "export option to Egypt", "construction of LNG", and "gas for peace". Turkey, under the circumstances that existed at that time was portrayed, as being economically, the only viable option for the Greek-Cypriots if they wanted their gas to journey to Europe. Politically, however, this option was conditioned on the need to discover more gas and, most importantly, on a peaceful settlement of the conflict. This led us to the second most prominent discourse on how the neo-functional paradigm could be effective 
in the very realities of the Cyprus conflict. The idea of establishing a peace-fund that would operate as an investment bank in order to improve the infrastructure on the Island was suggested. Furthermore, the low gas prices and the small amount of gas reserves detected so far, allegedly do not enable the construction of LNG. The export option to Egypt was also suggested, under the condition that the latter would not become energy self-sufficient in a couple of years.

In the second policy-paradigm, motivated by the "neorealist paradigm", the political and geopolitical expediencies behind the energy discussion were highlighted. The framing of "energy as a security issue", the "challenges for gas companies" the "geopolitical chessboard", and the historical "legacies of the conflict" were the main discourses set forth in this policy-paradigm. Both sides asserted that the energy debate has been hijacked by domestic expediencies. From the Greek-Cypriot viewpoint, the decision-making on the future monetization of the gas reserves should remain in their hands; the resulting profits, however, could be shared by both sides. The Turkish-Cypriots disagree with this rationale and claimed that the issue should be put on the negotiation table. The Greek-Cypriots are afraid that this might fuel the existing tensions and create a new problem in parallel with the Cyprus conflict one. They also fear that this would not remain a bicommunal issue because the Turkish-Cypriots might act as "the Trojan Horse of Turkey". The GreekCypriot side, after the 1974 events and the feeling of abasement it suffered, holds negative reflexes vis-à-vis Turkey's intentions on the Island. Furthermore, both sides agreed that the maritime disputes around the Island are linked to the diachronic dispute between Greece and Turkey in the Aegean. Finally, the psychomilieu of resentment that surrounds the Island, explains why the energy dispute was viewed from the angle of the existing conflict.

We will close our conclusions pointing to the difficulties inherent in such research enterprise. Both the Cyprus conflict and the energy security issue are so convoluted that multiple factors might not gain the attention they probably merit. Through the presentation of these policy paradigms the author sought to lay out which contradictory tendencies are at play. One of these tendencies is more likely to prevail under certain conditions than the other. But under which conditions one tendency would actually dominate cannot be accurately predicted. Furthermore, experience has shown that international politics are exposed to continuous change, because world affairs conceal surprises in store for everyone attempting to "read the future from his knowledge of the past and from signs of the present" (Morgenthau, 1948: 7). For instance, we do not actually know whether and how a potential crisis between Turkey and the RoC or between Turkey and Greece might alter the power configuration in the area. The best an author could do in such a situation is to trace the different tendencies and the likelihoods attached to them.

The most formidable challenge encountering a scientific inquiry into the nature and ways of international politics is the ambiguity of the material the analyst has to deal with. Since the author does not participate in the negotiations that take place between the two sides behind closed doors, he cannot set out which actual "truths" motivate the debate. Time pressure and "personal chemistry" between the negotiators are nonverbal variables in the conclusion of a negotiation that cannot be easily put on paper.

This assumption points to a vast difference between the academic and the policy world. Diplomacy and negotiations in every political debate are not only science but art as well: they constitute a "practice enacted in and on the world, in real time and with actual consequences for the practitioner" (Pouliot, 2010: 16). Seasoned diplomats are at pains to explain their craft in abstract terms, like commonsense - identified as the essence of diplomacy - intelligence and tact (ibid). These concepts cannot be taught in books or articles through the help of formal schemes since they do not crop up from conscious deliberations. The essence and practicality of diplomacy and negotiations cannot be fully captured by detached and representational observation (ibid). This does justice to the very difficulties researchers encounter while dealing with such sensitive issues.

\section{References}

1. Anderson Peter (2008). The divisions of Cyprus. in London Review of Books, 30(8), 7-16.

2. Athanasiou Thanos (11.7.2011). The tragedy in Mari [in Greek] in Sigmalive. Retrieved at http://www.sigmalive.com/timeliner/subjects/timeliner mari/timeline-mari.html (accessed on 18.3.2017).

3. Barnes Joe, Hayes Mark, Joffe Amy \& Victor David (eds.) (2006). Natural Gas and Geopolitics. From 1970 to 1940, Cambridge: Cambridge University Press. 
4. Blay SKN (1981). Self-Determination in Cyprus: The New Dimensions of an Old Conflict. Australian Year Book of International Law, 67-100.

5. Bleich Erik (2002). Integrating ideas into policy-making analysis: Frames and Race Policies in Britain and France". Comparative Political Studies, 35(9), 1054-1076.

6. Campbell J. (1998). Institutional analysis and the role of ideas in political economy. Theory and Society, 27(3), pp. 377-409.

7. Charmaz Kathy (2011). Qualitative Interviewing and Grounded Theory Analysis. in Holstein James \& Gubrium Jaber (eds.) Inside Interviewing, Sage Research Methods, http://methods. sagepub.com/book/inside-interviewing.

8. Correlje Aad \& van der Linde Coby (2006). Energy supply security and geopolitics: A European perspective. Energy Policy, 34, 532-543.

9. Gurel Ayrel, Mullen Fionna, Tzimitras Harry (2013). The Cyprus Hydrocarbons Issue: Context, Positions and Future Scenarios, in PRIO Cyprus Center Report 1/2013.

10. Gurel Ayrel and Le Cornu Laura (2014). Can Gas Catalyze Peace in the Eastern Mediterranean. The International Spectator: Italian Journal of International Affairs, 49(2), 11-33.

11. Hall Peter (1990). Policy Paradigms, Social Learning and the State: The Case of Economic Policy Making in Britain, Working Paper Series. Retrieved at http://www.march.es/ceacs/publicaciones/ working/archivos/1990_4_en.pdf (accessed on 12.11.2011).

12. Karakasis Vasileios (2013). The framing of the Euro crisis and the contribution of the German Policy Paradigm. International Journal of Human Rights and Constitutional Studies, 1(3), 224-249.

13. Karakasis Vasileios (2015). Energy Security and the Cyprus Question: "Securitization" of Energy in the Eastern Mediterranean. Politikon: IAPSS Political Science Journal, 27(1), 5-35.

14. Kuzemko Caroline (2014). Ideas, power and change: explaining EU energy relations. Journal of European Public Policy, 21(1), 58-75.

15. Morgenthau Hans (1948). Politics among Nations, New York: Knopf.

16. Pouliot Vincent (2010). International Security in Practice. The Politics of NATO-Russia Diplomacy, Cambridge: Cambridge University Press.

17. Saz Carranza Angel \& Marie Vandendriessche (2015). Routes to Energy Security: The Geopolitics of Gas Pipelines, in Steven David \& Emily O’Brien (eds.) The New Politics of Strategic Resources, Washington D.C.: Brookings Institution Press.

18. Seidel Gill (1985). Political Discourse Analysis, in Teun van Dijk (ed.). Handbook of Discourse Analysis, London: Academic.

19. Shaffer Brenda (2009). Energy Politics, Philadelphia: University of Pennsylvania Press.

20. Sovacool Benjamin \& Brown Marilyn (2010). Competing Dimensions of Energy Security: An International Perspective. Annual Review of Environment and Resources, 35(1), 77-108.

21. Spyridakis Constantinos (1974). A Brief History of Cyprus, Nicosia: Zavallis Press Limited.

22. Stavrou Michael (2009). Resolving the Cyprus Conflict Negotiating History, New York: Palgrave Macmillan.

23. Yergin Daniel (3rd ed.) (2009). The Prize. The Epic Quest for Oil, Money \& Power, New York: Free Press.

24. Yergin Daniel (2012). The Quest. Energy, Security and the Remaking of the New World, New York: The Penguin Press.

25. Weir Margaret and Skocpol Theda (1985). State Structures and the Possibilities for "Keynesian" Responses to the Great Depression in Sweden, Britain, and the United States, in Evans Peter (ed.). Bringing the state back in, Cambridge University Press, pp. 107-164.

26. Winrow Gareth (2016). The Anatomy of a Possible Pipeline: The Case of Turkey and Leviathan and Gas Politics in the Eastern Mediterranean. Journal of Balkan and Near Eastern Studies, 18(5), 431-447. 